\title{
Unbalanced 1q Whole-Arm Translocation Resulting in der(14)t(1;14)(q11-12;p11) in Myelodysplastic Syndrome
}

\author{
G. Fogu ${ }^{a, c}$ P.M. Campus ${ }^{c}$ F. Cambosu ${ }^{a}$ M.A. Moro ${ }^{a}$ R. Sanna ${ }^{a, c}$ C. Fozzab, \\ R.M. Nieddu ${ }^{b, c}$ M. Longinotti ${ }^{b, c}$ A. Montella ${ }^{a, c}$ \\ ${ }^{a}$ Clinical Genetics, Department of Biomedical Sciences, ${ }^{b}$ Institute of Hematology, University of Sassari, and \\ ${ }^{c}$ Azienda Ospedaliero Universitaria Sassari, Sassari, Italy
}

\section{Key Words}

Centromere $\cdot \mathrm{FISH} \cdot$ Myelodysplasia $\cdot 1 \mathrm{q}$ Whole-arm

translocation

\begin{abstract}
Unbalanced whole-arm translocations (WATs) of the long arm of chromosome 1, resulting in complete trisomy 1q, are chromosomal abnormalities detectable in both solid tumors and hematologic neoplasms. Among the WATs of 1q to acrocentric chromosomes, a few patients with der $(1 ; 15)$ described as a dicentric chromosome have been reported so far, whereas cases of $\operatorname{der}(1 ; 14)$ are much rarer. We report on a case of $\operatorname{der}(1 ; 14)$ detected as single anomaly in a patient with myelodysplastic syndrome. The aim of our work was to investigate the breakpoints of the $(1 ; 14)$ translocation leading to the der $(1 ; 14)$. Fluorescence in situ hybridization (FISH) experiments have been performed on chromosome preparations from bone marrow aspirate, using specific centromeric probes of both chromosomes, as well as a probe mapping to $1 \mathrm{q} 11$ band. FISH results showed that in our patient the derivative chromosome was monocentric with a unique centromere derived from chromosome 14. The breakpoints of the translocation were located in the short arm of chromosome 14 and in the long arm of chromosome 1, between the
\end{abstract}

alphoid D1Z5 and the satellite II domains. The 1q breakpoint was within the pericentromeric region of chromosome 1 , which is notoriously an unstable chromosomal region, involved in different chromosomal rearrangements.

Copyright $\odot 2012$ S. Karger AG, Basel

Trisomies of the long arm of chromosome 1, resulting from different chromosomal rearrangements, including tandem duplications as well as unbalanced, jumping and whole-arm translocations (WATs) of 1q, may be found in both solid tumors and hematologic disorders. Cases of solid tumors include Wilms' tumor [Kaneko et al., 1983] and hepatoblastoma [Parada et al., 2000; Tomlison et al., 2005], while, among hematologic disorders, cases of myelodysplastic syndrome (MDS), acute myelogenous leukemia (AML), chronic myelomonocytic leukemia and multiple myeloma (MM) have been reported [Mecucci et al., 1985; Alitalo et al., 1989; Fonatsch et al., 1991; Djordjević et al., 2008; Mitelman et al., 2011].

Unbalanced WATs of $1 \mathrm{q}$ are chromosomal aberrations which may involve different chromosomes [Mitelman et al., 2011]. The derivatives of these translocations have been shown to be dicentric in few cases of der(1;7) [Alitalo et al., 1989; Wang et al., 2003] and $\operatorname{der}(1 ; 15)$ [Wong

\section{KARGER \\ Fax +4161306 1234 \\ E-Mail karger@karger.ch}

www.karger.com
(C) 2012 S. Karger AG, Basel

$1424-8581 / 12 / 1364-0256 \$ 38.00 / 0$

Accessible online at:

www.karger.com/cgr
Giuseppina Fogu

Genetica Clinica, Dipartimento di Scienze Biomediche

Viale S. Pietro $43 / \mathrm{C}$

IT-07100 Sassari (Italy)

Tel. +39079228 534, E-Mail gfogu@uniss.it 
Fig. 1. G-banded karyotype. The arrow indicates the $\operatorname{der}(1 ; 14)$.

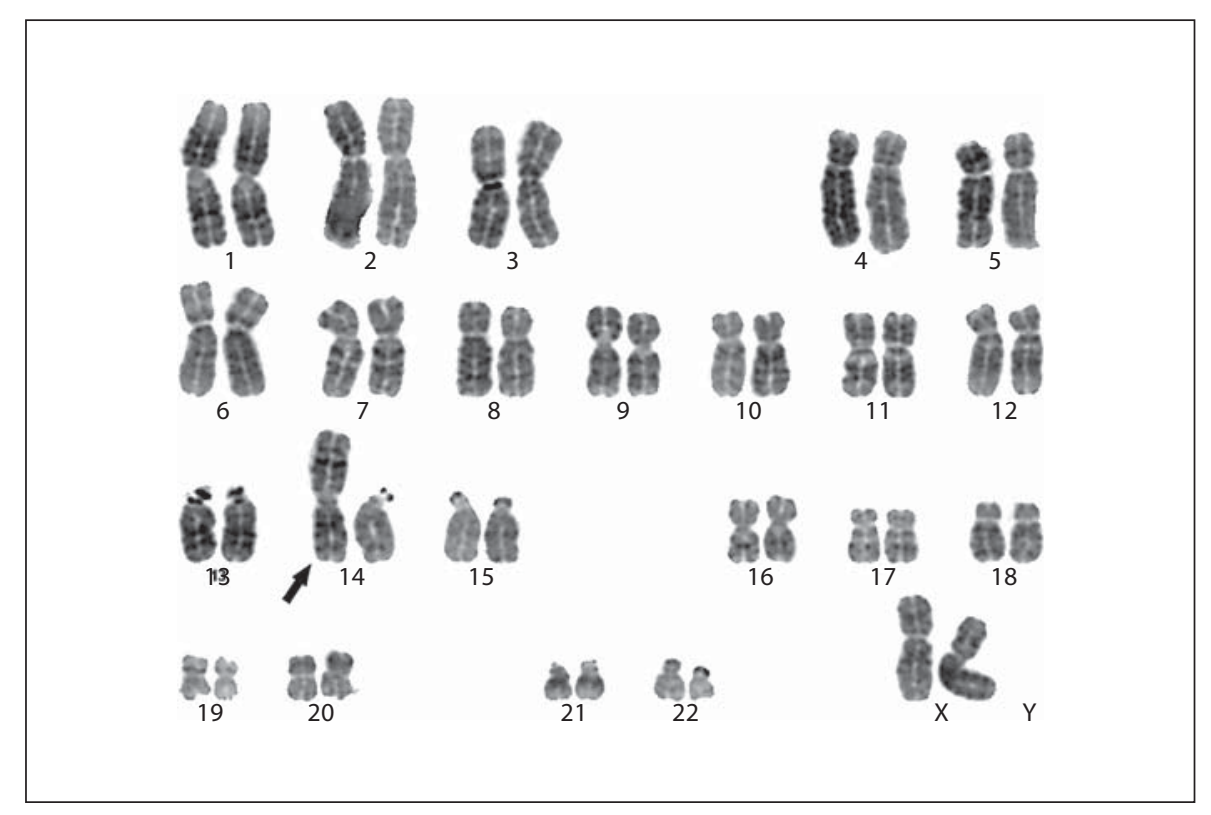

et al., 1995; Michaux et al., 1996]. Very few data are available about $\operatorname{der}(1 ; 14)$, which is a much rarer chromosomal rearrangement [Busson-Le Coniat et al., 1999; Djordjević et al., 2005]. Here we report on the findings of fluorescence in situ hybridization (FISH) studies performed in a patient with MDS showing this unusual translocation.

\section{Materials and Methods}

\section{Case Report}

The patient is a 72-year-old female, diagnosed with bone marrow aplasia in 1996, at 56 years. After a treatment with antilymphocytic globulin, cyclosporin A and testosterone she achieved complete remission which lasted until March 2004, when she came to our attention because of pancytopenia, slight splenomegaly and low-grade fever. Blood counts showed: hemoglobin $7.6 \mathrm{~g} / \mathrm{l}$, white blood cells $1.5 \times 10^{9} / 1$, platelets $110 \times 10^{9} / 1$. Bone marrow was hypocellular and showed signs of dysplasia involving more than $10 \%$ of the myeloid, erythroid and megakaryocytic lineage. Therefore, the diagnosis was refractory cytopenia with multilineage dysplasia according to the WHO classification [Swerdlow et al., 2008]. The patient was offered a treatment with erythropoietin plus standard supportive measures. Follow-up bone marrow evaluations showed a substantially stable morphological picture. In 2006 she also developed a systemic sarcoidosis which was satisfactorily controlled by a high-dose steroid treatment. At present the patient's conditions are good, without signs of evolution to AML. The first cytogenetic analyses, performed at the time of the diagnosis of marrow aplasia and during the long-lasting stationary phase of the disease, showed normal karyotype, thus making more likely that the chromosomal change observed during the evolution to MDS is therapy-related.

der $(1 ; 14)$ in Myelodysplasia

\section{Cytogenetic and FISH Studies}

Standard procedures were used for routine cytogenetics. Metaphases obtained from unstimulated bone marrow cells were analyzed in GTG- or QFQ-banding after 24/48-hour culture.

FISH studies were performed using the following commercial probes: whole chromosome painting probes of chromosomes 1 and 14 (wcpl, wcp14), centromeric probes of chromosome 1 (locus D1Z5 and satellite II/III (SAT II/III)), all supplied by Abbott Molecular/Vysis (Des Plaines, Ill., USA) and Alphoid probe 14/22 (locus D14Z1/D22Z1), supplied by Cytocell Ltd (Cambridge, UK). The slides for FISH were prepared according to standard procedures and subsequently co-denatured together with the probes at $73^{\circ} \mathrm{C}$ for 2 min using the Vysis Hybrite Hybridization System (Downers Grove, Ill., USA). Afterwards, they were incubated overnight at $37-42^{\circ} \mathrm{C}$ and detected according to the suppliers' instructions. The slides were then stained with DAPI and observed with Olympus BX61 fluorescence microscope using suitable filters.

\section{Results}

Both analyses on bone marrow blood were performed in 1996, when the patient was diagnosed with bone marrow aplasia, and in 2004 during follow-up, normal karyotype in all the examined cells was shown.

The first analyses on bone marrow blood were performed in 1996, when the patient was diagnosed with bone marrow aplasia, and in 2004 during follow-up, and normal karyotype in all the examined cells was shown. These analyses were performed by another cytogenetic laboratory, and therefore data about the number of screened cells are unavailable. 


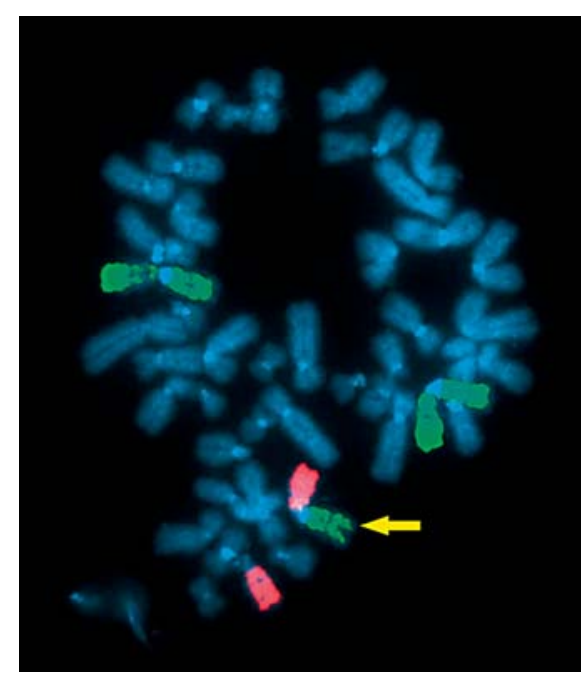

Fig. 2. FISH with wcp(1) (green) and wcp(14) (red). The arrow indicates the $\operatorname{der}(1 ; 14)$.

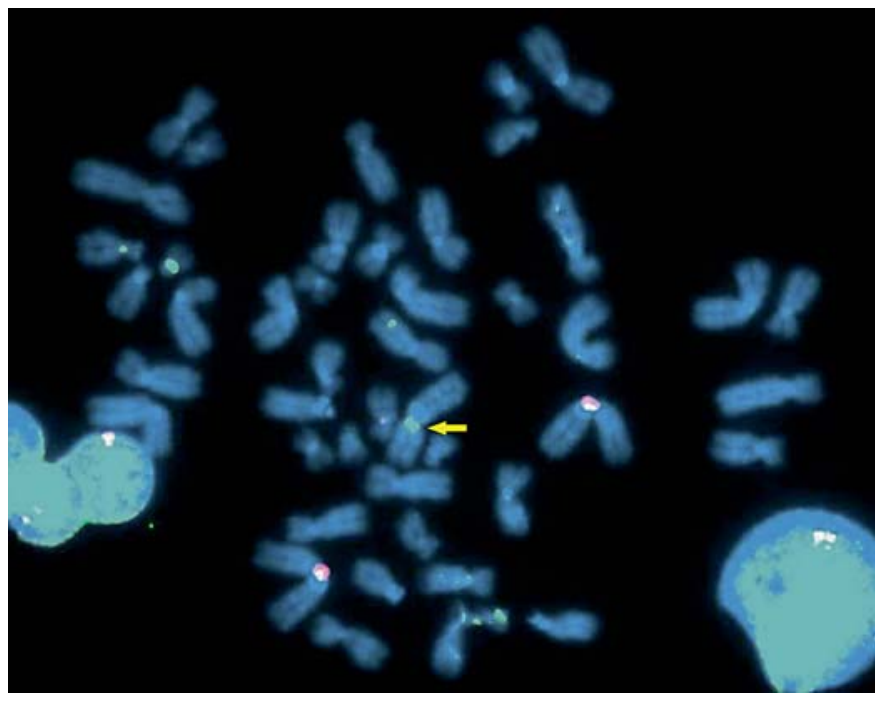

Fig. 3. FISH with CEP(1) (red) and CEP(14) (green). The der(1;14) indicated by an arrow shows a green spot only.

Table 1. Cytogenetic and clinical data of the present case

\begin{tabular}{llll}
\hline Year & Cytogenetics & Diagnosis & Therapy \\
\hline 1996 & $46, \mathrm{XX}$ & bone marrow aplasia & antilymphocytic globulin, cyclosporin, testosterone \\
\hline 2004 & $46, \mathrm{XX}$ & RCMD & erythropoietin, standard supportive therapies \\
\hline 2005 & $46, \mathrm{XX}, \operatorname{der}(14) \mathrm{t}(1 ; 14)(\mathrm{q} 11-12 ; \mathrm{p} 11)[11] / 46, \mathrm{XX}[14]$ & RCMD & standard supportive therapies \\
\hline 2006 & $46, \mathrm{XX}, \operatorname{der}(14) \mathrm{t}(1 ; 14)(\mathrm{q} 11-12 ; \mathrm{p} 11)[7]$ & $\begin{array}{l}\text { RCMD + systemic } \\
\text { sarcoidosis }\end{array}$ & $\begin{array}{l}\text { standard supportive therapies }+ \\
\text { high-dose steroid treatment }\end{array}$ \\
\hline 2010 & $46, \mathrm{XX}, \operatorname{der}(14) \mathrm{t}(1 ; 14)(\mathrm{q} 11-12 ; \mathrm{p} 11)[22] / 46, \mathrm{XX}[3]$ & RCMD & standard supportive therapies \\
\hline 2011 & $46, \mathrm{XX}, \operatorname{der}(14) \mathrm{t}(1 ; 14)(\mathrm{q} 11-12 ; \mathrm{p} 11)[15] / 46, \mathrm{XX}[5]$ & RCMD & standard supportive therapies \\
\hline
\end{tabular}

RCMD $=$ Refractory cytopenia with multilineage dysplasia.

In 2005 , the patient was admitted to the hematologic unit of our university. At that time, a standard cytogenetic analysis showed a mosaic of normal and pathological cells with a ratio of 14:11 between normal and abnormal cells. In the pathological clone 1 chromosome 14 was replaced by a rearranged chromosome, seemingly consisting of the long arm of chromosome 1 and the long arm of chromosome 14 (fig. 1). This interpretation was confirmed by FISH experiments with wcp probes of chromosomes 1 and 14 (fig. 2). The derivative chromosome, identified as $\operatorname{der}(1 ; 14)$, was positive for the alphoidspecific probe $\mathrm{CEP}(14 / 22)$ and negative for the alpha satellite probe of chromosome 1 (locus D1Z5) (fig. 3). The probe corresponding to the SAT II/III region of chromo- some 1 gave a positive signal on $\operatorname{der}(1 ; 14)$ (not shown). These findings clearly indicated that the translocation breakpoint on chromosome 1 was located between the D1Z5 and SAT II/III locus, so sparing the centromeric alphoid block, while the chromosome 14 had a breakpoint on its short arm, retaining its own centromere. The complete karyotype of the abnormal clone, according to the International System for Human Cytogenetic Nomenclature [ISCN, 2009], was: 46,XX,der(14)t(1;14) (q11-12;p11).ish der(14)(wcp1+,SAT II/III+,D1Z5-,D14Z1/ D22Z1+,wcp14+). Subsequent analyses, performed in February 2006, March 2010 and February 2011, confirmed the persistence of the abnormal clone (table 1). 
Table 2. Reported cases with centromere translocations involving 1p10 or 1q10 [Mitelman et al., 2011]

\begin{tabular}{|c|c|c|c|c|c|c|c|}
\hline Chromosome change & Total & $\begin{array}{l}\text { Non-hemato- } \\
\text { logic neoplasia }\end{array}$ & $\begin{array}{l}\text { Hematologic } \\
\text { malignancies }\end{array}$ & MDS/AML & $\begin{array}{l}\text { ALL/CLL/ } \\
\text { lymphoma }\end{array}$ & CMPD & $\begin{array}{l}\text { MM/plasma } \\
\text { cell leukemia }\end{array}$ \\
\hline $\operatorname{der}(1 ; 2)(\mathrm{p} 10$ or $\mathrm{q} 10 ; \mathrm{p} 10$ or $\mathrm{q} 10)$ & 12 & 8 & 4 & 1 & & & 3 \\
\hline $\operatorname{der}(1 ; 3)(\mathrm{p} 10$ or $\mathrm{q} 10 ; \mathrm{p} 10$ or $\mathrm{q} 10)$ & 18 & 17 & 1 & 1 & & & \\
\hline $\operatorname{der}(1 ; 4)(\mathrm{p} 10$ or $\mathrm{q} 10 ; \mathrm{p} 10$ or $\mathrm{q} 10)$ & 5 & 3 & 2 & & & & 2 \\
\hline $\operatorname{der}(1 ; 5)(\mathrm{p} 10$ or $\mathrm{q} 10 ; \mathrm{p} 10$ or $\mathrm{q} 10)$ & 15 & 7 & 8 & & 3 & & 5 \\
\hline $\operatorname{der}(1 ; 8)(\mathrm{p} 10$ or $\mathrm{q} 10 ; \mathrm{p} 10$ or $\mathrm{q} 10)$ & 16 & 9 & 7 & & 1 & & 6 \\
\hline $\operatorname{der}(1 ; 9)(\mathrm{p} 10$ or $\mathrm{q} 10 ; \mathrm{p} 10$ or $\mathrm{q} 10)$ & 19 & 7 & 12 & 1 & 5 & 1 & 5 \\
\hline $\operatorname{der}(1 ; 10)(\mathrm{p} 10$ or $\mathrm{q} 10 ; \mathrm{p} 10$ or $\mathrm{q} 10)$ & 3 & 2 & 1 & 1 & & & \\
\hline $\operatorname{der}(1 ; 11)(\mathrm{p} 10$ or $\mathrm{q} 10 ; \mathrm{p} 10$ or $\mathrm{q} 10)$ & 12 & 10 & 2 & & 1 & & 1 \\
\hline $\operatorname{der}(1 ; 16)(\mathrm{p} 10$ or $\mathrm{q} 10 ; \mathrm{p} 10$ or $\mathrm{q} 10)$ & 125 & 67 & 58 & 5 & 3 & 1 & 49 \\
\hline $\operatorname{der}(1 ; 17)(\mathrm{p} 10$ or $\mathrm{q} 10 ; \mathrm{p} 10$ or $\mathrm{q} 10)$ & 15 & 5 & 10 & 3 & 4 & 1 & 2 \\
\hline $\operatorname{der}(1 ; 18)(\mathrm{p} 10$ or $\mathrm{q} 10 ; \mathrm{p} 10$ or $\mathrm{q} 10)$ & 6 & 1 & 5 & 2 & & 2 & 1 \\
\hline $\operatorname{der}(1 ; 19)(\mathrm{p} 10$ or $\mathrm{q} 10 ; \mathrm{p} 10$ or $\mathrm{q} 10)$ & 22 & 9 & 13 & & 1 & & 12 \\
\hline $\operatorname{der}(1 ; 20)(\mathrm{p} 10$ or $\mathrm{q} 10 ; \mathrm{p} 10$ or $\mathrm{q} 10)$ & 2 & & & 1 & 1 & & \\
\hline $\operatorname{der}(1 ; 21)(\mathrm{p} 10$ or $\mathrm{q} 10 ; \mathrm{p} 10$ or $\mathrm{q} 10)$ & 21 & 9 & 12 & 3 & 3 & 2 & 4 \\
\hline $\operatorname{der}(1 ; 22)(\mathrm{p} 10$ or $\mathrm{q} 10 ; \mathrm{p} 10$ or $\mathrm{q} 10)$ & 12 & 6 & 6 & 1 & 1 & & 4 \\
\hline
\end{tabular}

$\mathrm{ALL}=$ Acute lymphoblastic leukemia; $\mathrm{AML}=$ acute myeloid leukemia; $\mathrm{CLL}=$ chronic lymphoblastic leukemia; $\mathrm{CMPD}=\mathrm{chronic}$ myeloproliferative disease; $\mathrm{MDS}=$ myelodysplastic syndrome; $\mathrm{MM}=$ multiple myeloma.

\section{Discussion}

Unbalanced WATs of chromosome 1q, which involve centromeric or pericentromeric regions of different chromosomes, differ from the typical balanced reciprocal translocations. In fact the abnormal clone retains 2 copies of an apparently normal chromosome 1 and only 1 out of the 2 possible derivatives, resulting in complete trisomy 1q, associated with partial monosomy of the partner chromosome. As reported in table 2, the extra 1q may be fused with different recipient chromosomes, but some rearrangements, such as $\operatorname{der}(1 ; 7), \operatorname{der}(1 ; 16)$ and $\operatorname{der}(1 ; 15)$, seem to recur in different hematological malignancies [Mitelman et al., 2011]. In particular, der(1;7), which is the most frequent WAT of 1q, is non-randomly distributed among neoplastic hematological diseases, with a large prevalence in MDS/AML. The der $(1 ; 16)$ is the second most frequent 1q WAT and is prevalent in MM. Other lq rearrangements seem to be randomly shared among solid and hematological tumors, among which myeloid and lymphoid neoplasms are nearly equally involved. These differences could reflect the effects of the concomitant partial aneuploidy of the partner chromosome, which always occurs in this peculiar chromosomal rearrangement, namely monosomy $7 \mathrm{q}$ in $\operatorname{der}(1 ; 7)$ and monosomy $16 \mathrm{p}$ in $\operatorname{der}(1 ; 16)$. Another not less relevant aspect is that the derivative chromosome 1 is not often a single anomaly but is part of complex karyotypes.

The molecular mechanism of translocations involving the entire $\mathrm{q}$ arm of chromosome 1 has been exhaustively investigated by Alitalo et al. [1989] and Wang et al. [2003] on several patients with der(1;7). These authors showed that the derivative chromosome contains 4 alphoid subsets, 2 from chromosome 1 and 2 from chromosome 7. They also demonstrated that the breakpoints on chromosome 1 are randomly distributed in different patients inside the alphoid block D1Z7. Therefore, the $(1 ; 7)$ translocation indicated as $\operatorname{der}(1 ; 7)(\mathrm{q} 10 ; \mathrm{p} 10)$ or $(\mathrm{q} 10 ; \mathrm{q} 10)$ gives rise to a dicentric chromosome. 
Table 3. Cases with der(1;14) according to Mitelman et al. [2011] and present case

\begin{tabular}{|c|c|c|c|c|c|}
\hline Author & $\begin{array}{l}\text { Age/ } \\
\text { sex }\end{array}$ & Disease & Karyotype & $\begin{array}{l}\text { Previous exposure to } \\
\text { toxic agents }\end{array}$ & Survival \\
\hline Swolin et al., 1986 & $59 / \mathrm{M}$ & post PV MDS & $46, \mathrm{XY},+1, \operatorname{der}(1 ; 14)(\mathrm{q} 10 ; \mathrm{q} 10)$ & busulfan & $\begin{array}{l}6 \text { months } \\
\text { after MDS }\end{array}$ \\
\hline Ben-Neriah et al., 1991 & $1 / \mathrm{M}$ & bilineage leukemia & $47, \mathrm{XY},-14,+\operatorname{der}(14) \mathrm{t}(1 ; 14)(\mathrm{q} 11 ; \mathrm{p} 11),+22$ & $\begin{array}{l}\text { aracytin, dauno- } \\
\text { mycin, etoposide }\end{array}$ & 1 year \\
\hline Nylund et al., 1994 & $28 / \mathrm{F}$ & ALL/LL & $46, \mathrm{XX},+1, \operatorname{der}(1 ; 14)(\mathrm{q} 10 ; \mathrm{q} 10), \operatorname{der}(19) \mathrm{t}(1 ; 19)(\mathrm{q} ? 23 ; \mathrm{p} ? 13)$ & de novo & \\
\hline Hashimoto et al., 1995 & $54 / \mathrm{M}$ & NHL & $47, \mathrm{XY},+\mathrm{X}[6] / 35-42, \mathrm{XY}, \operatorname{der}(1 ; 13)(\mathrm{q} 10 ; \mathrm{q} 10), \operatorname{der}(1 ; 14)(\mathrm{p} 10 ; \mathrm{q} 10)[\mathrm{cp} 4] / 46, \mathrm{XY}[11]$ & de novo & \\
\hline Uckun et al., 1998 & ?/F & ALL & $46, \mathrm{XX}, \mathrm{t}(1 ; 19)(\mathrm{q} 23 ; \mathrm{p} 13), \operatorname{der}(14) \mathrm{t}(1 ; 14)(\mathrm{q} 11 ; \mathrm{p} 11)$ & & \\
\hline $\begin{array}{l}\text { Busson-Le Coniat et al., } \\
1999\end{array}$ & $65 / \mathrm{M}$ & PV & 47,XY,der(14)t(1;14)(q11;p11) & & \\
\hline Schoch et al., 2001 & $49 / \mathrm{F}$ & $\begin{array}{l}\text { acute monoblasti } \\
\text { leukemia FAB M5A }\end{array}$ & $46, \mathrm{XX},+\mathrm{i}(5)(\mathrm{p} 10),+8, \operatorname{der}(14) \mathrm{t}(1 ; 14)(\mathrm{q} 11 ; \mathrm{p} 11)$ & & \\
\hline Chan et al., 2003 & $59 / \mathrm{F}$ & Burkitt/leukemia & $\begin{array}{l}47, \mathrm{X}, \operatorname{add}(\mathrm{X})(\mathrm{p} 22),+7, \mathrm{t}(8 ; 14)(\mathrm{q} 24 ; \mathrm{q} 32)[2] / 47, \text { idem,add(7)(p22)[5]/47,idem,+1, } \\
\operatorname{der}(1 ; 21)(\mathrm{q} 10 ; \mathrm{q} 10)[42] / 47, \operatorname{idem},+1, \operatorname{der}(1 ; 14)(\mathrm{q} 10 ; \mathrm{q} 10)[2]\end{array}$ & & \\
\hline Andrieux et al., 2003 & $64 / \mathrm{F}$ & post PV MF & $46, \mathrm{XX}, \operatorname{der}(1 ; 14) \mathrm{t}(1 ; 14)(\mathrm{q} 10 ; \mathrm{p} 10)$ & pipobroman & $\begin{array}{l}2 \text { years } \\
\text { after PPMF }\end{array}$ \\
\hline Harrison et al., 2003 & ?/M & MM & $\begin{array}{l}\text { 46,X,-Y,dic(1;6)(q10;q15) } \times 2, \operatorname{der}(4) \mathrm{t}(4 ; 14)(\mathrm{p} 16 ; \mathrm{q} 32), \operatorname{der}(8) \mathrm{t}(8 ; 13)(\mathrm{q} 24 ; \mathrm{q} 14) \times 2 \\
\operatorname{der}(13) \mathrm{t}(8 ; 13)(\mathrm{q} 24 ; \mathrm{q} 14) \operatorname{dup}(13)(\mathrm{q} 14.3 \mathrm{q} 14.3),-13, \operatorname{der}(1 ; 14)(\mathrm{q} 10 ; \mathrm{q} 10) \mathrm{t}(4 ; 14)(\mathrm{p} 16 ; \mathrm{q} 32) \\
\operatorname{dic}(1 ; 17)(\mathrm{q} 10 ; \mathrm{q} 25)[7]\end{array}$ & & \\
\hline Imashuku et al., 2003 & $11 / \mathrm{F}$ & RAEB & $46, \mathrm{XX},+1, \operatorname{der}(1 ; 14)(\mathrm{q} 10 ; \mathrm{q} 10) / 46, \mathrm{idem}, \mathrm{add}(9)(\mathrm{q} 34), \operatorname{add}(17)(\mathrm{p} 11)$ & & \\
\hline Harada et al., 2004 & $69 / \mathrm{M}$ & $\begin{array}{l}\text { secondary MDS/ } \\
\text { RAEBt }\end{array}$ & $46, \mathrm{XY}, \operatorname{del}(12)(\mathrm{p} 12), \operatorname{der}(14) \mathrm{t}(1 ; 14)(\mathrm{p} 10 ; \mathrm{p} 10)$ & atomic bomb exposure & \\
\hline Zamora et al., 2004 & ?/F & PV & 46,XX,der(14)t(1;14)(q10;q10)[8]/46,XX[12] & de novo & \\
\hline $\begin{array}{l}\text { Barouk-Simonet et al., } \\
2005\end{array}$ & $73 / \mathrm{M}$ & RARS & $\begin{array}{l}\text { 45-46,der(1;14)(p10;q10),del(5)(q13;q33),+8,+9, del(11)(q14),del(20)(q11), } \\
\operatorname{der}(21) \mathrm{t}(21 ; 21)(?, ?) \cdot \operatorname{ish}(\mathrm{AML} 1-; \mathrm{BCR}+),-22[\mathrm{cp}]\end{array}$ & & \\
\hline Keller et al., 2006 & $68 / \mathrm{F}$ & NHL & $\begin{array}{l}51, \mathrm{XX},+\mathrm{X},+2, \operatorname{in}(3)(\mathrm{q} 26 \mathrm{q} 27),+12, \mathrm{t}(14 ; 18)(\mathrm{q} 32 ; \mathrm{q} 21), \operatorname{der}(14) \mathrm{t}(1,14)(\mathrm{q} 11 ; \mathrm{p} 11),+17 \\
\operatorname{dup}(17)(\mathrm{q} 21 \mathrm{q} 25) \times 2,+18\end{array}$ & & \\
\hline Adeyinka et al., 2007 & $65 / \mathrm{M}$ & ALL & $46, \mathrm{XY},+1, \operatorname{der}(1 ; 4)(\mathrm{q} 10 ; \mathrm{q} 10)[14] / 46, \mathrm{XY}[6]$ & & \\
\hline Adeyinka et al., 2007 & $73 / \mathrm{M}$ & MM & $46, \mathrm{XY},+1, \operatorname{der}(1 ; 4)(\mathrm{q} 10 ; \mathrm{q} 10)[4] / 46, \mathrm{XY}[6]$ & & \\
\hline Adeyinka et al., 2007 & $74 / \mathrm{M}$ & MPD & $46, \mathrm{XY},+1, \operatorname{der}(1 ; 4)(\mathrm{q} 10 ; \mathrm{q} 10)$ & & \\
\hline Stamatoullas et al., 2007 & $30 / \mathrm{M}$ & $\mathrm{HL}$ & 46,X,-Y,del(4)(q28),+8,add(9)(p24),der(14)t(1;14)(q11;p11),der(21)t(1;21)(q11;p11) & & \\
\hline $\begin{array}{l}\text { Douet-Guilbert et al., } \\
2008\end{array}$ & $51 / \mathrm{M}$ & PV & $47, \mathrm{XY},+9, \operatorname{der}(14) \mathrm{t}(1 ; 14)(\mathrm{q} 11 ; \mathrm{p} 11), \operatorname{del}(20)(\mathrm{q} 12)[19] / 46, \mathrm{XY}[1]$ & & \\
\hline Lee et al., 2008 & $10 / \mathrm{M}$ & AML M4 & $46, \mathrm{XY},+1, \operatorname{der}(1 ; 14)(\mathrm{q} 10 ; \mathrm{q} 10)$ & de novo & \\
\hline Djordjević et al., 2008 & $43 / \mathrm{M}$ & CMML & $46, \mathrm{XY},+1, \operatorname{der}(1 ; 14)(\mathrm{q} 10 ; \mathrm{q} 10)$ & de novo & \\
\hline Millington et al., 2008 & $79 / \mathrm{F}$ & MDS & 46,XX,der(14)t(1,14)(q11;p13)[14]/46,XX[6] & de novo & 1 year \\
\hline Present case & $65 / \mathrm{F}$ & RCMD & $46, \mathrm{XX},+1, \operatorname{der}(1 ; 14)(\mathrm{q} 11-12 ; \mathrm{p} 11)$ & $\begin{array}{l}\text { antilymphocytic } \\
\text { globulin, cyclosporin } \\
\text { A, testosterone }\end{array}$ & \\
\hline \multicolumn{6}{|c|}{$\begin{array}{l}\quad \mathrm{ALL}=\text { Acute lymphoblastic leukemia; } \mathrm{AML}=\text { acute myeloid leukemia; } \mathrm{CMML}=\text { chronic myelomonocytic leukemia; } \mathrm{F}=\text { female; } \mathrm{HL}=\mathrm{Hodgkin} \text { lymphoma; } \\
\mathrm{LL}=\text { lymphoblastic lymphoma; } \mathrm{M}=\text { male; } \mathrm{MF}=\mathrm{myelofibrosis} \text {; } \mathrm{MDS}=\text { myelodysplastic syndrome; } \mathrm{MM}=\text { multiple myeloma; } \mathrm{MPD}=\text { myeloproliferative disease; } \mathrm{NHL}=\text { non- } \\
\text { Hodgkin lymphoma; } \mathrm{PV}=\text { polycythemia vera; } \mathrm{PPMF}=\text { myelofibrosis after polycythemia vera; } \mathrm{RAEB}=\text { refractory anemia with excess of blasts; } \mathrm{RAEBt}=\text { refractory anemia with } \\
\text { excess of blasts in transformation; RARS = refractory anemia with ringed sideroblasts; } \mathrm{RCMD}=\text { refractory cytopenia with multilineage dysplasia. }\end{array}$} \\
\hline
\end{tabular}

WATs of 1q to acrocentric chromosomes may be interesting to define the role of 1q trisomy in different tumors. In fact, only in cases where the recipient chromosome is an acrocentric and the 1q WAT is present as isolated karyotypic abnormality, the resulting chromosome imbalance may be considered as pure 1q trisomy. Indeed, the loss of the $\mathrm{p}$ arm of acrocentric chromosomes is irrelevant, similarly to what occurs in constitutional Robertsonian translocations, which do not seem to have phenotypic effect in normal carriers.

The most common WAT translocation involving an acrocentric chromosome is der $(1 ; 15)$, reported in 33 he- matologic patients with myeloid and lymphoid malignancies. FISH studies have been performed by Michaux et al. [1996] to investigate the role of centromeric sequences of both chromosomes in the origin of der $(1 ; 15)$. Authors showed the dicentric nature of the $\operatorname{der}(1 ; 15)$ chromosome in 1 out of 3 patients reported and they suggested that the preservation of both centromeres could be a constant occurrence in translocation of $1 \mathrm{q}$ to chromosome 15.

The unbalanced translocation leading to $\operatorname{der}(1 ; 14)$ present in our patient is not a common chromosomal rearrangement. From Mitelman et al. [2011] database we 
have collected 23 cases of hematologic patients by using different searching criteria, i.e. karyotype formulae which have apparently the same meaning, such as 'der(14) $\mathrm{t}(1 ; 14)(\mathrm{q} 11 ; \mathrm{p} 11)$ ', ' $+1, \operatorname{der}(1 ; 14)$ ', 'der(1;14)(p10 or q10;p10 or q10)' or similar. Clinical and cytogenetic data of patients with der( $1 ; 14)$, including ours, are reported in table 3. Among these patients the male sex is prevalent (14:10) and the median age at diagnosis, calculated on 21 patients (data were not available for 3 patients) is 59 years. Over $60 \%$ of patients (15/24) had a diagnosis of myeloid disorder, including AML, MDS and myeloproliferative disease, while the remaining patients had acute lymphoblastic leukemia/lymphoma or MM; 5 cases had polycythemia vera or myelofibrosis/MDS after polycythemia vera, in agreement with the high incidence of $1 \mathrm{q}$ trisomy already reported in these conditions [Swolin et al., 1986, 2008; Andrieux et al., 2003].

For most patients reported in table 2, information about therapy and survival from diagnosis are incomplete, so that it is really hard to reach any firm conclusion about them.

All but 2 reported cases of der $(1 ; 14)$ have been investigated by standard cytogenetic methods; FISH experiments with centromere-specific probes of chromosomes 1 and 14 are available for 2 patients [Busson-Le Coniat et al., 1999; Djordjević et al., 2005]. Busson-Le Coniat et al. [1999] reported FISH results of 1 patient with polycythemia vera and Djordjević et al. [2005] on 1 patient with chronic myelomonocytic leukemia. In the former, the der $(1 ; 14)$ was negative for the chromosome 1-specific alpha satellite probe D1Z5, while it was positive for a chromosome 1-specific SAT II probe. According to FISH findings, the der $(1 ; 14)$ was interpreted as a monocentric chromosome, with a unique centromere derived from chromosome 14. The breakpoint on 1q was located between the alphoid D1Z5 and the SAT II domain. In the latter case, the $\operatorname{der}(1 ; 14)$ was positive for a FISH probe specific for the secondary constriction of 1q (pUC1.77, 1q12-1q21), but no FISH results were available for the alpha satellite-specific probe.

In the present case, FISH findings show that the $\operatorname{der}(1 ; 14)$ has a unique centromere derived from chromosome 14, similarly to that observed by Busson-Le Coniat et al. [1999] in their patient. Future studies should further explore whether the mechanism shown as responsible for the occurrence of $\operatorname{der}(1 ; 14)$ in our patient is common in 1q WATs to chromosome 14 .

Translocations with fusion of 2 chromosome arms, either of homologous or non-homologous chromosomes, produce a derivative chromosome often described as di- centric, although the translocation breakpoints are mostly unknown.

Most of these centromeric fusions involve chromosomes with large $\mathrm{C}$ bands, corresponding to large blocks of constitutive centromeric heterochromatin. They are variable in size in normal individuals, mainly at the centromeres of chromosomes 1, 9, and 16, and are known as common heteromorphisms. Centromeric translocations involving chromosome 1 , which result in gain of $1 \mathrm{q}$ due to the persistence of 2 apparently normal chromosomes 1, may occur with different mechanisms: a primary duplication of a whole chromosome 1, which precedes the subsequent centromere translocation, or, alternatively, the centromere translocation could precede and perhaps predispose to a subsequent duplication of the entire chromosome 1 [Andersen and Pedersen-Bjergaard, 2000]. Another model suggests a simultaneous WAT and duplication of 1q, subsequent to heterochromatin decondensation, which seems to have a primary role in this rearrangement [Sawyer et al., 1998; Wong et al., 2001].

Centromeric translocations typically do not involve key genes, whose disruption may account for neoplastic proliferation, as observed in several neoplasias, but they usually have as main consequence gain or loss of the entire whole arms of the involved chromosomes. Concerning the unbalanced $t(1 ; 14)$ described in our patient, the main consequence is a genomic imbalance resulting from gain of the long arm of chromosome 1. Trisomies of entire arms are likely implicated in neoplastic processes by a gene dosage effect, analogous to what is reported for numerical aberrations, such as trisomy 8 or other full trisomies. The 1q trisomy implies a deregulation of several genes likely implicated in the control of normal cell cycle kinetics, with a consequent alteration of the balance between proliferation and cell death. Up-regulation of genes mapped to lq has been shown by gene expression profiling analyses in MM patients with gain of 1q [Shaughnessy et al., 2006], which suggests that gene deregulation could be the main mechanism of tumorigenesis in 1q rearrangements in these patients and likely in other tumors.

Therefore, other mechanisms could be implied, such as heterochromatin-dependent oncogenic mechanisms, as suggested by Fournier et al. [2007]. Constitutive heterochromatin is a specialized compartment within the chromatin and is found primarily at centromeres, telomeres and the pericentromeric regions of certain chromosomes, including chromosome 1 . It is composed of gene-poor, repetitive DNA sequences (alpha satellite, SAT II, III) with a pre-eminent role in the control of genome 
stability, but it is also relevant for epigenetic control of gene expression through a process termed gene silencing. The involvement of 1q12 SAT II-rich constitutive heterochromatin in several 1q rearrangements suggests that this chromosomal region is absolutely important for initiating and/or progression of different tumors. Our case highlights that FISH studies with appropriate probes of chromosomal rearrangements involving 1q heterochromatin could be helpful to improve our knowledge about this portion of the human genome, mainly concerning its possible role in the pathogenesis of neoplastic disorders.

\section{References}

Adeyinka A, Wei S, Sanchez J: Loss of $17 \mathrm{p}$ is a major consequence of whole-arm chromosome translocations in hematologic malignancies. Cancer Genet Cytogenet 173:136143 (2007).

-Alitalo T, Willard HF, de la Chapelle A: Determination of the breakpoints of $1 ; 7$ translocations in myelodysplastic syndrome by in situ hybridization using chromosome-specific alpha satellite DNA from human chromosomes 1 and 7. Cytogenet Cell Genet 50:4953 (1989).

Andersen MK, Pedersen-Bjergaard J: Increased frequency of dicentric chromosomes in therapy-related MDS and AML compared to de novo disease is significantly related to previous treatment with alkylating agents and suggests a specific susceptibility to chromosome breakage at the centromere. Leukemia 14:105-111 (2000).

Andrieux J, Demory JL, Caulier MT, Agape P, Wetterwald M, et al: Karyotypic abnormalities in myelofibrosis following polycythemia vera. Cancer Genet Cytogenet 140:118-123 (2003).

-Barouk-Simonet E, Soenen-Cornu V, Roumier C, Cosson A, Lai JL, et al: Role of multiplex FISH in identifying chromosome involvement in myelodysplastic syndromes and acute myeloid leukemias with complex karyotypes: a report on 28 cases. Cancer Genet Cytogenet 157:118-126 (2005).

-Ben-Neriah S, Abramov A, Lerer I, Polliack A, Leizerowitz R, et al: 'Jumping translocation' in a 17-month-old child with mixed-lineage leukemia. Cancer Genet Cytogenet 56:223229 (1991).

Busson-Le Coniat M, Salomon-Nguyen F, Dastugue $\mathrm{N}$, Maarek O, Lafage-Pochitaloff $\mathrm{M}$, et al: Fluorescence in situ hybridization analysis of chromosome 1 abnormalities in hematopoietic disorders: rearrangements of DNA satellite II and new recurrent translocations. Leukaemia 13:1975-1981 (1999).

-Chan NP, Ma E, Wan TSK, Chan LC: The spectrum of acute lymphoblastic leukemia with mature B-cell phenotype. Leuk Res 27:231234 (2003).

Djordjević V, Jankovic G, Suvajd N, Marisavljevic D, Pantic M, et al: A der(14)t $(1 ; 14)$ (q12;p11) in chronic myelomonocytic leukaemia. Cancer Genet Cytogenet 160:89-93 (2005).
Djordjević V, Dencić-Fekete M, Jovanović J, Drakulić D, Stevanović M, et al: Pattern of trisomy 1q in hematological malignancies: a single institution experience. Cancer Genet Cytogenet 186:12-18 (2008)

Douet-Guilbert N, Basinko A, Morel F, Le Bris MJ, Ugo V, et al: Chromosome 20 deletions in myelodysplastic syndromes and Philadelphia-chromosome-negative myeloproliferative disorders: characterization by molecular cytogenetics of commonly deleted and retained regions. Ann Hematol 87:537-544 (2008).

Fonatsch C, Haase D, Freund M, Bartels H, Tesch $\mathrm{H}$, et al: Partial trisomy 1q. A nonrandom primary chromosomal abnormality in myelodysplastic syndromes.Cancer Genet $\mathrm{Cy}$ togenet 56:243-253 (1991)

Fournier A, Florin A, Lefebvre C, Solly F, Leroux $D$, et al: Genetics and epigenetics of $1 \mathrm{q}$ rearrangements in hematological malignancies. Cytogenet Genome Res 118:320-327 (2007).

Harada H, Harada Y, Niimi H, Kyo T, Kimura A, et al: High incidence of somatic mutations in the $A M L 1 / R U N X 1$ gene in myelodysplastic syndrome and low blast percentage myeloid leukemia with myelodisplasia. Blood 103: 2316-2324 (2004).

Harrison CJ, Mazzullo H, Cheun KL, Gerrard G, Jalai GR, et al: Cytogenetics of multiple myeloma: interpretation of fluorescence in situ hybridization results. Br J Haematol 120: 944-952 (2003).

Hashimoto K, Miura I, Chyubaki A, Saito M, Miura $\mathrm{AB}$ : Correlations of chromosome abnormalities with histologic and immunologic characteristics in 49 patients from Akita, Japan with non-Hodgkin lymphoma. Cancer Genet Cytogenet 81:56-65 (1995).

Imashuku S, Hibi S, Bessho F, Tsuchida M, Nakahata T, et al: Detection of myelodysplastic syndrome/acute myeloid leukemia evolving from aplastic anemia in children treated with recombinant human G-CSF. Haematologica 88:ECR31 (2003).

ISCN 2009: An International System for Human Cytogenetic Nomenclature (S. Karger, Basel 2009).

Kaneko Y, Kondo K, Rowley JD, Moohr JW, Maurer HS: Further chromosome studies on Wilms' tumor cells of patients without aniridia. Cancer Genet Cytogenet 10:191-197 (1983).
- Keller CE, Nandula S, Vakiani E, Alobeid B, Murty VV, et al: Intrachromosomal rearrangement of chromosome 3q27: an under recognized mechanism of BCL6 translocation in B-cell non-Hodgkin lymphoma. Hum Pathol 37:1093-1099 (2006).

Lee HR, Kang SH, Kang HJ, Shin HY, Ahn HS, et al: Lineage switch from acute myeloid leukemia to biphenotypic acute leukemia with acquisition of Philadelphia chromosome. Cancer Genet Cytogenet 184:124-126 (2008).

Mecucci C, Ghione F, Tricot G, Van de Berghe H: Combined trisomy $1 \mathrm{q}$ and monosomy $7 \mathrm{q}$ due to translocation 1;7 in myelodysplastic syndrome. Cancer Genet Cytogenet 18:193-197 (1985).

-Michaux L, Dierlamm J, Mecucci C, Meeus P, Ameye G, et al: Dicentric $(1 ; 15)$ in myeloid disorders. Cancer Genet Cytogenet 88:8689 (1996).

Millington K, Hudnall SD, Northup J, Panova N, Velagaleti G: Role of chromosome 1 pericentric heterochromatin (1q) in pathogenesis of myelodysplastic syndromes: report of 2 new cases. Exp Mol Pathol 84:189-193 (2008).

Mitelman F, Johansson B, Mertens F: Database of Chromosome Aberrations and Gene Fusions in Cancer: http://cgap.nci.nih.gov/ Chromosomes/Mitelman (2011).

Nylund SJ, Ruutu T, Saarinen U, Knuutila S: Metaphase fluorescence in situ hybridization (FISH) in the follow-up of 60 patients with haemopoietic malignancies. Br J Haematol 88:778-783 (1994).

- Parada LA, Limon J, Iliszko M, Czauderna P, Gisselsson D, et al: Cytogenetics of hepatoblastoma: further characterization of 1q rearrangements by fluorescence in situ hybridization - an international collaborative study. Med Pediatr Oncol 34:165-170 (2000).

-Sawyer JR, Tricot G, Mattox S, Jagannath S, Barlogie B: Jumping translocations of chromosome 1q in multiple myeloma: evidence for a mechanism involving decondensation of pericentromeric heterochromatin. Blood 91: 1732-1741 (1998).

Schoch C, Bursch S, Kern W, Schnittger S, Hiddemann W, et al: Gain of an isochromosome $5 p$ : a new recurrent chromosome abnormality in acute monoblastic leukemia. Cancer Genet Cytogenet 127:85-88 (2001). 
Shaughnessy JD Jr, Zhan F, Burington BE, Huang Y, Colla S, et al: A validate gene expression model of high-risk multiple myelo$\mathrm{ma}$ is defined by deregulated expression of genes mapping to chromosome 1. Blood 109: 2276-2284 (2006).

-Stamatoullas A, Piquenot JM, Dusmenil C, Ruminy $\mathrm{P}$, Penther D, et al: Conventional cytogenetics of nodular lymphocyte-predominant Hodgkin's lymphoma. Leukemya 21: 2064-2067 (2007).

Swerdlow SH, Campo E, Harris NL, Jaffe ES, Pileri SA, et al: WHO Classification of Tumours of Haematopoietic and Lymphoid Tissues (IARC, Lyon 2008).

- Swolin B, Weinfeld A, Westin J: Trisomy 1q in polycytemia vera and its relation to disease transition. Am J Hematol 22:155-167 (1986).
Swolin B, Rödjer S, Westin J: Therapy-related patterns of cytogenetic abnormalities in acute myeloid leukemia and myelodysplastic syndrome post polycythemia vera: single center experience and review of literature. Ann Hematol 87:467-474 (2008).

Tomlison GE, Douglass EC, Pollock BH, Finegold MJ, Schneider NR: Cytogenetic evaluation of a large series of hepatoblastomas: numerical abnormalities with recurring aberrations involving 1q12-q21. Genes Chromosomes Cancer 44:177-184 (2005).

Uckun FM, Sensel MG, Sather HN, Gaynon PS, Arthur DC, et al: Clinical significance of translocation $\mathrm{t}(1 ; 19)$ in childhood acute lymphoblastic leukemia in the context of contemporary therapies: a report from the Children's Cancer Group. J Clin Oncol 16:527535 (1998).
-Wang L, Ogawa S, Hangaishi A, Qiao Y, Hosoya $\mathrm{N}$, et al: Molecular characterization of the recurrent unbalanced translocation der $(1 ; 7)$ (q10;p10). Blood 102:2597-2604 (2003).

Wong KF, Hayes KJ, Glassman AB: der $(1 ; 15)$ (q10;q10): A nonrandom chromosomal abnormality of myeloid neoplasia. Cancer Genet Cytogenet 83:144-147 (1995).

Wong N, Lam WC, Pang E, Lau WY, Johnson PJ: Hypomethylation of chromosome 1 heterochromatin DNA correlates with q-arm copy gain in human hepatocellular carcinoma. Am J Pathol 159:465-471 (2001).

Zamora L, Espinet B, Florensa L, Besses R, Woessner S, et al: Is fluorescence in situ hybridization a useful method in diagnosis of polycythemia vera patients? Cancer Genet Cytogenet 151:139-145 (2004). 